\title{
Combining Ability, Heterosis, and Heritability of Storage Root Dry Matter, Beta-Carotene, and Yield-related Traits in Sweetpotato
}

\author{
Fekadu Gurmu' \\ South Agricultural Research Institute, Hawassa Research Center, Hawassa, \\ Ethiopia
}

\author{
Shimelis Hussein and Mark Laing \\ African Center for Crop Improvement, University of KwaZulu-Natal, \\ Pietermaritzburg, South Africa
}

Additional index words. combining ability, gene action, orange-fleshed sweetpotato, vitamin A deficiency

\begin{abstract}
Orange-fleshed sweetpotato (OFSP) is an effective, low-priced, and sustainable source of $\beta$-carotene (provitamin A). However, most OFSP varieties have low storage root dry matter content (DMC), which influences their acceptance by small-scale farmers and hence needs to be improved. The objective of the study was to determine the combining ability, type of gene action, heterosis and heritability of storage root DMC, $\beta$-carotene content, and yield-related traits of selected sweetpotato clones for further evaluation and breeding. Crosses were conducted using a $7 \times 7$ half-diallel mating design and a total of 28 genotypes (seven parents and 21 crosses) were evaluated at four locations in Ethiopia using a $7 \times 4$ alpha lattice design with two replications. The performance of the genotypes was significantly different $(P<0.01)$ across the four locations for storage root DMC, $\beta$-carotene content, sweetpotato virus disease (SPVD) reaction, storage root yield, and harvest index (HI). The general combining ability (GCA) and specific combining ability (SCA) mean squares were significant $(P<0.01)$ for all traits except the SCA effect of storage root DMC. The GCA to SCA variance ratios were $0.96,0.94$, $\mathbf{0 . 7 4 , 0 . 9 6}$, and 0.97 for storage root DMC, $\beta$-carotene content, SPVD, fresh storage root yield, and HI, respectively, indicating that the inheritance of these traits was controlled mainly by additive genes. Progenies of crosses involving Ukerewe $\times$ Ejumula, Ukerewe $\times$ Pipi, Resisto $\times$ Pipi, and Ejumula $\times$ Pipi exhibited high levels of positive heterosis for storage root DMC. Similarly, progenies of crosses including Resisto $\times$ Pipi and Resisto $\times$ Ogansagan had higher positive heterosis for fresh storage root yield, reflecting the breeding value of these parents. Relatively high narrow sense heritability $\left(h^{2}\right)$ was obtained for $\beta$-carotene content $(79.8 \%)$ and HI (48.6\%). However, the $h^{2}$ estimates of storage root DMC, SPVD, and fresh storage root yield were relatively low at $\mathbf{1 9 . 0 \%}$, $14.9 \%$, and $20.4 \%$, respectively. Crosses with high $\beta$-carotene content such as Ukerewe $\times$ Resisto, Resisto $\times$ Ogansagan, Eumula $\times$ Pipi, and NASPOT $1 \times$ Temesgen exhibited high storage root DMC. These families also had medium-to-high mean fresh storage root yield. Therefore, progenies derived from these families are good candidates to develop improved OFSP varieties with high storage root DMC.
\end{abstract}

Sweetpotato [Ipomoea batatas (L.) Lam] belongs to the morning glory family (Convolvulaceae) and originated in Latin America (Gichuki et al., 2003; Lebot, 2010; Zhang et al., 2000). It is cultivated in over 100 developing countries and ranks among the

Received for publication 11 July 2017. Accepted for publication 27 Nov. 2017.

The Alliance for a Green Revolution in Africa, International Foundation for Science, and Syngenta Foundation are duly acknowledged for financially supporting the study.

We thank the Southern Agricultural Research Institute in Ethiopia for the provision of facilities during the execution of the field works.

${ }^{1}$ Corresponding author. E-mail: fekadugb@gmail. com. five most important food crops in more than 50 of those countries (Andrade et al., 2009). It is one of the most widely grown storage root crops in sub-Saharan Africa (SSA). Sweetpotato is one of the food security crops in Ethiopia grown by smallholder farmers (Gurmu et al., 2015a; Tadesse, 2006; Tofu et al., 2007). It is among well-known and established crops in southern, eastern, and southwestern parts of Ethiopia. Sweetpotato covered over 59,000 ha with production of more than 2.7 million tons in the 2014/15 cropping season (CSA, 2015).

Ethiopia's targets for sweetpotato improvement include improving storage root yield, resistance to major diseases (sweetpotato viruses) and insect pests (sweetpotato weevil and sweetpotato butterfly). SPVD is one of the major problems of sweetpotato production and productivity in east Africa where it is reported every cycle of production (Karyeija et al., 1998). In addition, enhancing the nutritional traits of sweetpotato varieties is another major focus area, among which improving $\beta$-carotene content (provitamin A) is the top priority. Breeding for high $\beta$-carotene content is crucial because vitamin A deficiency (VAD) is a serious health problem that results in blindness, weak resistance, and death (Gurmu et al., 2015b; Low et al., 2001; van Jaarsveld et al., 2005; Wang et al., 2011; WHO, 2009). VAD especially affects preschool children and pregnant and lactating mothers. About 140-190 million children aged less than 5 years are estimated to have low serum retinol concentrations, $<0.7 \mu \mathrm{mol} \cdot \mathrm{L}^{-1}$ (WHO, 2009). Almost 100 million of these children live in south Asia and SSA (Low et al., 2001; van Jaarsveld et al., 2005; WHO, 2009). Most countries in SSA are categorized as having a public health problem concerning clinical and subclinical VAD (WHO, 2009). Some 3 million children in SSA less than the age of 5 suffer from partial or total blindness as a result of VAD.

There are various strategies that are devised to tackle the problem of VAD, among which biofortification is the most affordable and sustainable one (Gurmu et al., 2015b). HarvestPlus leads the global biofortification effort. It is part of the Consultative Group for International Agricultural Research Program on Agriculture for Human Nutrition. HarvestPlus is working on biofortification with a number of partners, including governments, nongovernmental organizations, and the private sector. Under the support of the HarvestPlus program, biofortified crops have been officially released and are being grown by farmers mainly in Asia and Africa. Some of the countries that released biofortified crop varieties with the support of HarvestPlus are Bangladesh (zinc-rich rice), India (iron-rich pearl millet), Democratic Republic of Congo (iron-rich beans, provitamin A cassava), Nigeria (provitamin A cassava, provitamin A maize), Rwanda (iron-rich beans), Uganda (provitamin A sweetpotato, iron-rich beans), and Zambia (provitamin A maize) (Low et al., 2017; HarvestPlus, 2014, 2017). A number of SSA countries released OFSP as a source of provitamin A (Kapinga et al., 2010). In 2016, the World Food Prize was awarded to four scientists to recognize their valuable contributions in research, development and popularization of OFSP varieties (Low et al., 2017; HarvestPlus, 2017).

In Ethiopia, some OFSP varieties have been released with the support of the International Potato Center (CIP) and are being heavily promoted (Tofu et al., 2007). OFSP is a good source of provitamin A that is cheap staple food compared with other sources such as animal products and expensive vegetables. It is also an easily accessible and year-round source of provitamin A (Burri, 2011; Gurmu et al., 2015b; van Jaarsveld et al., 2005). However, the acceptance of the OFSP varieties by farmers and consumers is low mainly due to their low storage root DMC (Gurmu et al., 2015a). Farmers prefer to grow the 
white-fleshed sweetpotato varieties that have high storage root DMC. On the other hand, the white-fleshed sweetpotato varieties have no $\beta$-carotene. To date, there has been no strategic breeding program in Ethiopia targeted at enhancing storage root DMC of OFSP varieties to increase their acceptability and adoption. Therefore, improving the storage root DMC of the OFSP varieties in Ethiopia through a designed breeding program and their popularization is vital to enhance their adoption by farmers and thereby improve vitamin $\mathrm{A}$ intake of various communities.

Controlled crossing can be conducted using mating designs such as diallel. Diallel analysis involves four methods (Griffing, 1956a). Method 1 involves all possible crosses (direct and reciprocal) including parents, which is a full diallel. In half diallel, Method 2 considers direct crosses and parents only, whereas Method 3 uses all possible crosses without parents and Method 4 evaluates direct crosses only (Griffing, 1956a).

The diallel design is a genetic design that has been widely used in genetic analyses to determine the genetic control of quantitative traits (Hayman, 1954, 1958; Jinks and Hayman, 1953), to assess GCA and SCA effects (Griffing, 1956a, 1956b) and to determine heterosis (Gardner and Eberhart, 1966; Gardner, 1967). It is used to estimate the genetic variance components between crosses (Griffing, 1956a; Hayman, 1954; Jinks and Hayman, 1953; Kempthorne, 1956, 1957), where the relative magnitude of GCA and SCA variances indicate the type of gene action and the best selection method leading to optimal genetic gain. The GCA variances and their effects indicate predominance of additive gene action, whereas the SCA effects indicate nonadditive gene action (dominance, overdominance, or epistasis) in controlling the expression of traits. Therefore, the objective of this study was to determine the combining ability, type of gene action, heterosis and heritability of storage root DMC, $\beta$-carotene content, and yield-related traits of selected sweetpotato clones for further evaluation and breeding.

\section{Materials and Methods}

\section{Study sites}

A crossing block was established at the South Agricultural Research Institute in Hawassa, Ethiopia. Hawassa $\left(7^{\circ} 03^{\prime} 54^{\prime \prime} \mathrm{N}\right.$ and $38^{\circ} 28^{\prime} 59^{\prime \prime} \mathrm{E}$ ) is located $275 \mathrm{~km}$ south of the Ethiopian capital, Addis Ababa. The progeny tests were conducted at four locations (Hawassa, Wondogenet, Arbaminch and Dilla) in the Southern Nation, Nationalities, and People's Region of Ethiopia. The details of the test sites are summarized in Table 1.

\section{Plant materials and crosses}

It was planned to use a $10 \times 10$ North Carolina Design II (Hallauer et al., 2010) involving 20 parents. However, only seven of the 20 parents produced sufficient flowers for the desired crosses and to collect enough seeds for subsequent analyses. Consequently, the study opted to use diallel mating design to

Table 1. Description of the study sites.

\begin{tabular}{lccccc}
\hline & & & & \multicolumn{2}{c}{ Mean annual temp $\left({ }^{\circ} \mathrm{C}\right)$} \\
\cline { 3 - 5 } Location & Altitude (masl)* & Coordinates & Annual rainfall $(\mathrm{mm})$ & Minimum & Maximum \\
\hline Hawassa & 1,700 & $07^{\circ} 03^{\prime} \mathrm{N}, 38^{\circ} 28^{\prime} \mathrm{E}$ & $1,046.3$ & 13.3 & 27.6 \\
Wondogenet & 1,742 & $07^{\circ} 19^{\prime} \mathrm{N}, 38^{\circ} 38^{\prime} \mathrm{E}$ & $1,372.0$ & 11.5 & 26.2 \\
Arbaminch & 1,400 & $06^{\circ} 03^{\prime} \mathrm{N}, 37^{\circ} 33^{\prime} \mathrm{E}$ & 940.9 & 17.4 & 30.6 \\
Dilla & 1,519 & $06^{\circ} 22^{\prime} \mathrm{N}, 38^{\circ} 18^{\prime} \mathrm{E}$ & $1,354.6$ & 12.9 & 28.1 \\
\hline
\end{tabular}

masl = meter above sea level.

Source: National Meteorological Agency, Hawassa Main Branch.

undertake possible cross combinations and to generate enough seeds from the limited number of parents. Hand crosses were performed in 2013 using a $7 \times 7$ half-diallel mating design in a net-house. Three parents were orange fleshed, two were yellow fleshed, and two were white fleshed with high DMC. Five of the varieties were introductions from the CIP, whereas two were released varieties in Ethiopia (Table 2). The criteria for parental selection were high storage root DMC of the white-fleshed sweetpotatoes, high $\beta$-carotene content of the OFSPs, flowering ability, or compatibility of the clones. The varieties planted for crossing were introduced from CIP/Nairobi as tissue culture (TC) plantlets and propagated at Areka Agricultural Research Center TC laboratory in Ethiopia. However, only five of those varieties produced sufficient flowers as indicated earlier. The two Ethiopian varieties were also obtained from Areka TC laboratory in Ethiopia as cleaned planting materials.

\section{Preparation of seeds, growing seedlings, and progeny evaluation}

The F1 seeds developed from the crosses were scarified by soaking in concentrated sulfuric acid (98\%) for $40 \mathrm{~min}$. Then the seeds were rinsed with tap water for $5 \mathrm{~min}$ to remove the acid (Lebot, 2010). A floating technique was used to separate viable and nonviable seeds by immersing the seeds into a $200 \mathrm{~mL}$ beaker containing water. Germination evaluation and subsequent planting of the scarified seeds was conducted by sowing the seeds in petri dishes.

The germinated seeds were planted in polystyrene seedling trays filled with a mixture of topsoil, sand, and manure in the ratio of $3: 1: 1$, in that order, and later transplanted to plastic pots of $10 \mathrm{~L}$ capacity containing the same media. From the F1 seedling plants, $20-30 \mathrm{~cm}$ long vine cuttings were prepared from each pot. One family was represented by 20 sibs. Cuttings from the F1 seedlings and the parents were planted in the field at four sites for progeny evaluation.

At each test site, the 28 sweetpotato families and parents ( 21 crosses and seven parents) were established using a $7 \times 4$ alpha lattice design with two replications. Alpha lattice design is an incomplete block design that is used especially when the number of treatments are relatively large and where soil heterogeneity at the test site is high. Per replication, a two-row plot of $3 \mathrm{~m}$ long was used for each family to accommodate the 20 sibs per family. A plot consisted of 20 full sibs per family. Data were recorded from surviving plants that ranged from 18 to 20 plants per family and mean values were reported. The study on heterosis involved a separate experiment with 24 full sibs selected among the 420 sibs (21 family $x$ 20 sibs). Heterosis was calculated based on storage root yields on plot basis using several clonal plants (20 plants) of each genotype (sib), and data were collected from the surviving plants. The interrow spacing was $1 \mathrm{~m}$ and intrarow spacing was $0.30 \mathrm{~m}$. The spacing between blocks and replications was 1 and $2 \mathrm{~m}$, respectively.

\section{Data collection}

The following five traits were considered for the genetic analysis. These included storage root DMC - expressed as percentage of storage root dry weight $(\mathrm{g})$ to fresh storage root weight $(\mathrm{g})$. Fresh storage root samples of 100-200 g were taken from each plant in the family and later dried in an oven at $80^{\circ} \mathrm{C}$ for $48 \mathrm{~h}$ to determine storage root DMC. The $\beta$-carotene content was analyzed at the Melkassa Agricultural Research Center in Ethiopia using spectrophotometry according to the protocol developed by Rodriguez-Amaya (2001) and the results were expressed as $\mu \mathrm{g} / 100 \mathrm{~g}$. The $\beta$-carotene content analysis was carried out on samples of two locations (Hawassa and Wondogenet) because of the limited capacity of the laboratory. Fresh storage root yield was expressed in gram per plant averaged over the 20 plants in each family. HI was calculated as a ratio of fresh storage root yield to total fresh biomass (aboveground fresh weight + storage root fresh weight) on family basis. The SPVD was recorded on a single plant basis using a scale of 1 to 9 ; where $1=$ no visible virus symptoms; 3 = faint mosaic; $5=$ mosaic clear; $7=$ heavy mosaic and stunted; $9=$ necrosis (dead patches). The scales were adapted and modified from previous reports (Hahn, 1979; Grüneberg et al., 2010; Mwanga et al., 2002a; Ndunguru et al., 2009; Shumbusha et al., 2014a).

\section{Data analyses}

Analysis of variance. ANOVA of data across environments was conducted using GenStat 14th edition (Payne et al., 2011) and SAS version 9.3 (SAS Institute Inc., 2003) statistical packages.

Estimation of GCA and SCA, heritability, and heterosis. The statistical model for the combined ANOVA across environments for the genetic analysis followed Hallauer et al. (2010):

$$
\begin{aligned}
Y_{i j k l}= & \mu+E_{\mathrm{e}}+k(\mathrm{re})_{k}+g_{i}+g_{j}+s_{i j}+g E_{i \mathrm{e}} \\
& +s E_{\mathrm{e} i j}+\varepsilon_{i j k l}
\end{aligned}
$$

where $Y_{i j k l}$ is the observed measurement for the $i j$ th cross grown in the $l$ th environment; $\mu$ is the grand mean; $E_{\mathrm{e}}$ is environment effect; 
Table 2. List of the seven sweetpotato parents used in a diallel crosses.

\begin{tabular}{|c|c|c|c|c|c|c|c|}
\hline No. & Genotypes & Root flesh color & SRDMC (\%) & Source & Resistance to SPVD & Country of release & References \\
\hline 1 & Ukerewe & Pale orange & 28.5 & CIP & Unknown & Tanzania & Teye and Abano (2012) \\
\hline 2 & Resisto & Deep orange & 25.0 & CIP & Susceptible & United States & Jones et al. (1983) \\
\hline 3 & Ejumula & Deep orange & 29.0 & CIP & Susceptible & Uganda & Mwanga et al. (2007) \\
\hline 4 & Pipi & Pale yellow & 31.5 & CIP & Resistant & - & - \\
\hline 5 & NASPOT 1 & Pale yellow & 26.5 & CIP & Resistant & Uganda & Mwanga et al. (2003) \\
\hline 6 & Temesgen & White & 33.0 & Ethiopia & Susceptible & Ethiopia & AARC (2015) \\
\hline 7 & Ogansagan & White & 34.5 & Ethiopia & Unknown & Ethiopia & AARC (2015) \\
\hline
\end{tabular}

$\mathrm{CIP}=$ International Potato Center; SRDMC $=$ storage root dry matter content; SPVD $=$ sweetpotato virus disease

$k(\mathrm{re})_{k}$ is the estimate of the $k$ th incomplete block within replications nested in the environment; $g_{i}+g_{j}$ are the GCA effects of $i$ th and $j$ th parents, respectively; $s_{i j}$ is the SCA effect; $g E_{i \mathrm{e}}$ is the interaction effect between GCA and the environment; $s E_{\mathrm{e} i j}$ is the interaction effect between SCA and the environment; $\varepsilon_{i j k l}$ is the error term associated with the $i j$ th cross evaluated in the $k$ th replication and $E_{\mathrm{e}}$ environment.

The GCA and SCA variance components were computed according to Griffing's (1956b) fixed-effects Model I, Method 2 (parents and $\mathrm{F} 1 \mathrm{~s}$ excluding reciprocals) using the DIALLEL-SAS05 program developed by Zhang et al. (2005). Sources of variation were partitioned as presented in the partial ANOVA of Table 3.

The type of gene action was calculated according to Baker (1978) and was expressed as the ratio of variances $2 \sigma_{\mathrm{GCA}}^{2} /$ $\left(2 \sigma_{\mathrm{GCA}}^{2}+\sigma_{\mathrm{GCA}}^{2}\right)$. If the ratio is closer to unity, it indicates predominance of additive gene action and greater predictability of progeny performance based on GCA effects.

Narrow sense heritability was estimated from the outputs of DIALLEL-SAS05 program as follows:

$$
h^{2}=\sigma_{\mathrm{GCA}}^{2} /\left(\sigma_{\mathrm{GCA}}^{2}+\sigma_{\mathrm{SCA}}^{2}+\sigma_{E}^{2}\right)
$$

where $h^{2}=$ narrow sense heritability estimates; $\sigma_{\mathrm{GCA}}^{2}=$ genetic variance for GCA; $\sigma_{\mathrm{SCA}}^{2}=$ genetic variance for SCA; and $\sigma_{E}^{2}=$ error variance

Heterosis is expressed as heterotic increment or heterotic gain for clonally propagated crops, where the parents are not inbred lines. Midparent-mid-offspring heterosis increment is used as a parameter to obtain information about the exploitable amount of heterosis (Grüneberg et al., 2015). Therefore, the midparent heterosis in this study refers to midparent-mid-offspring heterosis.

Midparent heterosis (MPH) and betterparent heterosis $(\mathrm{BPH})$ were estimated for storage root DMC, SPVD, and fresh storage root yield using the formula of Falconer and Mackay (1996):

$$
\begin{aligned}
\operatorname{MPH}(\%)= & ((\mathrm{F} 1-\mathrm{MP}) / \mathrm{MP}) \\
& \times 100 \text { and } \mathrm{BPH}(\%) \\
= & ((\mathrm{F} 1-\mathrm{BP}) / \mathrm{BP}) \times 100
\end{aligned}
$$

where $\mathrm{F} 1=$ mean of the $\mathrm{F} 1$ hybrid, $\mathrm{MP}=$ mean of the two parents involved in the cross, and $\mathrm{BP}=$ mean of better parent in the cross.

\section{Results}

Analysis of variance and mean performance of genotypes. The combined ANOVA of storage

Table 3. Analysis of variance of a half diallel including parents and their crosses repeated over environments using Griffing's (1956) Model I, Method 2.

\begin{tabular}{lll}
\hline Source of variation & \multicolumn{1}{c}{ df } & $E(\mathrm{MS})$ \\
\hline Environments $(E)$ & $\mathrm{e}-1$ & \\
Replications $/ E$ & $\mathrm{e}(r-1)$ & $s_{E}^{2}+r s^{2}{ }_{\mathrm{e} n}+e r K^{2}{ }_{n}$ \\
Treatments & {$[n(n+1) / 2]-1$} & \\
GCA & $n-1$ & \\
SCA & $n(n-3) / 2$ & \\
$E \times$ GCA & $(\mathrm{e}-1)(n-1)$ & \\
$E \times$ SCA & $(\mathrm{e}-1)[n(n-3) / 2]$ & $s_{E}^{2}$ \\
Pooled error & $\mathrm{e}(r-1)\{[n(n+1) / 2]-1\}$ & \\
Total & {$[\operatorname{ern}(n+1) / 2]-1$} & \\
\hline
\end{tabular}

$\mathrm{df}=$ degrees of freedom; $\mathrm{e}=$ environment; GCA $=$ general combining ability; $n=$ number of parents; $r=$ replication; $\mathrm{SCA}=$ specific combining ability.

root DMC, $\beta$-carotene content, SPVD, fresh storage root yield, and $\mathrm{HI}$ is presented in Table 4. There was a highly significant $(P<0.001)$ difference between genotypes across the four test environments for all the five traits. Genotype $\times$ environment interaction variances were also significant except for storage root DMC.

The sweetpotato genotypes, Temesgen and Ogansagan, had the highest storage root DMC of $35.5 \%$ and $36.0 \%$, respectively, whereas the lowest $(25.2 \%)$ was recorded for Resisto (Table 5). Crosses of Ukerewe $\times$ Pipi and Pipi $\times$ Ogansagan provided the highest mean storage root DMC of $40.5 \%$ and $40.8 \%$, respectively, across the four locations. Resisto had the highest mean $\beta$-carotene content of $11,103.4 \mu \mathrm{g} / 100 \mathrm{~g}$ followed by Ukerewe, which provided a mean $\beta$-carotene content of $8934.2 \mu \mathrm{g} / 100 \mathrm{~g}$ across locations. Temesgen and Ogansagan had the lowest mean $\beta$-carotene content of 34.7 and $26.0 \mu \mathrm{g} / 100 \mathrm{~g}$, respectively. The highest $\beta$-carotene content was recorded for the crosses Ukerewe $\times$ Resisto and Resisto $\times$ Ogansagan with means of 9844.7 and 10,590.3 $\mu \mathrm{g} / 100 \mathrm{~g}$, respectively (Table 5).

All parents except Temesgen had SPVD scores less than 3.0. Temesgen, with a mean score of 3.75, was susceptible (Table 5). All the crosses showed SPVD scores of 1.0-2.3. Resisto and NASPOT 1 had high mean fresh storage root yields of 982.7 and $969.8 \mathrm{~g} /$ plant, respectively. The cross Resisto $\times$ NASPOT 1 had the highest mean fresh storage root yield of $1020.6 \mathrm{~g} / \mathrm{plant}$, followed by the crosses Resisto $\times$ Pipi, Ukerewe $\times$ Resisto and Resisto $\times$ Temesgen, which had mean fresh storage root yields of 978.6, 958.1, and 952.5 $\mathrm{g} /$ plant, respectively. Across the four environments, Resisto had the highest HI with a mean of 0.56 across locations. The family of Resisto $\times$ NASPOT 1 recorded high $\mathrm{HI}$ of 0.52 , followed by the cross Resisto $\times$ Pipi, which had a mean HI of 0.50 (Table 5).
Combining ability effects. The GCA and SCA mean squares for storage root DMC, $\beta$-carotene content, SPVD, fresh storage root yield, and HI from a combined analysis of the four locations were highly significant except for the SCA of storage root DMC (Table 6).

GCA $\times$ environment and SCA $\times$ environment interaction effects were highly significant $(P<0.001)$ for all traits except storage root DMC (Table 6). The GCA to SCA variance ratios were 0.74 for SPVD, 0.96 for fresh storage root yield, 0.97 for HI, 0.96 for storage root $\mathrm{DMC}$, and 0.94 for $\beta$-carotene content.

Percent contributions of GCA and SCA were also calculated from the sum of squares of GCA and SCA values of all the five traits and the result is shown in Table 6 . The percent contribution of GCA was higher in four traits, namely storage root $\mathrm{DMC}, \beta$-carotene content, fresh storage root yield, and HI. Accordingly, GCA contributed 3.7 times more than SCA for storage root DMC, 2.4 times more for $\beta$-carotene content, 3.5 times more for fresh storage root yield, and 6.4 times for HI. For SPVD, SCA provided a higher contribution and was 2.5 times GCA.

GCA effects. The GCA effects of the parents, Ukerewe, Pipi, Resisto, and NASPOT 1 were positive and significant for storage root DMC (Table 7). The other three parents showed nonsignificant GCA effects for this trait. Ukerewe and Resisto showed positive and highly significant $(P<0.001)$ GCA effects for $\beta$-carotene content. Similarly, Ejumula showed a positive GCA effect at $P<0.05$. On the other hand, the other four parents, Pipi, NASPOT 1, Temesgen, and Ogansagan had highly significant $(P<0.001)$ GCA effects that were negative (Table 7).

Desirable GCA effects for SPVD should be negative. Resisto exhibited positive and highly significant $(P<0.001)$ GCA effects for SPVD in an undesirable direction. Temesgen also had positive and significant $(P<0.5) \mathrm{GCA}$ effects, confirming their historic susceptibilities 
Table 4. Analysis of variance showing the $\mathrm{df}$ and mean square values of five traits of seven sweetpotato parents and their 21 crosses evaluated across four locations.

\begin{tabular}{|c|c|c|c|c|c|c|c|}
\hline \multirow[b]{2}{*}{ Source of variation } & \multirow[b]{2}{*}{ df } & \multirow{2}{*}{$\frac{\text { Mean square }}{\beta \text {-carotene content }(\mu \mathrm{g} / 100 \mathrm{~g})}$} & \multirow[b]{2}{*}{$\mathrm{df}$} & \multicolumn{4}{|c|}{ Mean square } \\
\hline & & & & SRDMC (\%) & SPVD (1-9 score) & Fresh root yield (g/plant) & $\mathrm{HI}$ \\
\hline Environment $(E)$ & 1 & $9,959,719.0^{* * *}$ & 3 & $339.40 * * *$ & $12.22 * * *$ & $3,971,492.62 * * *$ & $0.316^{* * *}$ \\
\hline Replication $(R)$ & 1 & $4,048,715.0^{*}$ & 4 & $20.19^{\mathrm{Ns}}$ & $6.38 * * *$ & $9,101.23^{\mathrm{NS}}$ & $0.024 * * *$ \\
\hline Genotypes $(G)$ & 27 & $49,364,618.0^{* * *}$ & 27 & $27.18 * * *$ & $2.56 * * *$ & $371,175.29 * * *$ & $0.088 * * *$ \\
\hline$G \times E$ & 27 & $2,818,286.0 * * *$ & 81 & $15.86^{\mathrm{Ns}}$ & $0.89^{*}$ & $182,205.26^{* * *}$ & $0.008 * * *$ \\
\hline Error & 54 & $906,010.0$ & 108 & 11.56 & 0.70 & $16,906.80$ & 0.003 \\
\hline Total & 111 & & 223 & & & & \\
\hline
\end{tabular}

* **,***Significant at $P<0.05, P<0.01$, or $P<0.001$, respectively.

$\mathrm{df}=$ degrees of freedom; $\mathrm{HI}=$ harvest index; $\mathrm{NS}=$ nonsignificant; SPVD = sweetpotato virus disease; SRDMC $=$ storage root dry matter content.

Table 5. Means of five traits of seven sweetpotato parents and 21 crosses evaluated across four test locations in southern Ethiopia.

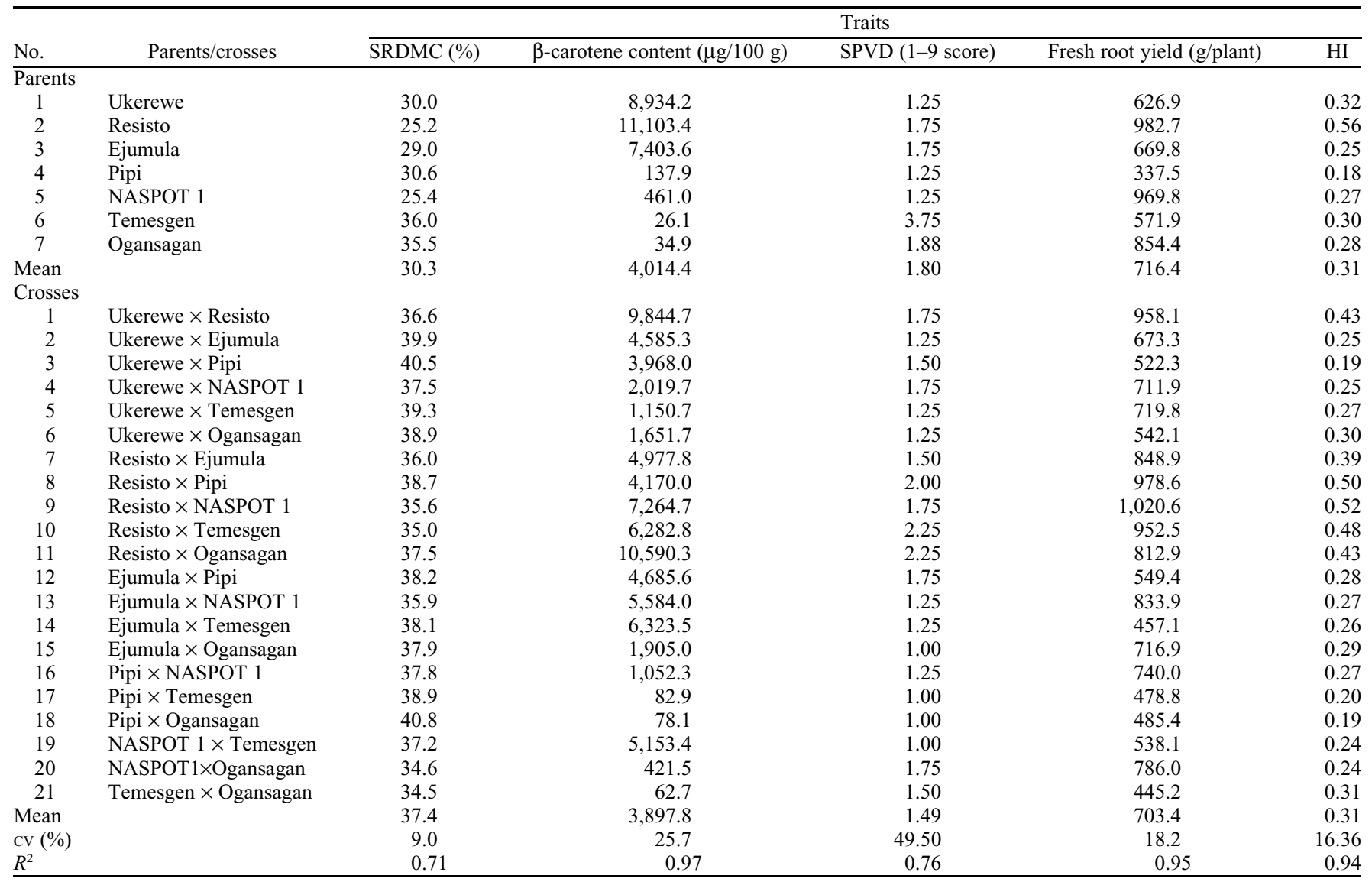

$\mathrm{HI}=$ harvest index; RDMC $=$ storage root dry matter content; SPVD = sweetpotato virus disease.

to SPVD. The GCA effects of other parents were not significant for this trait (Table 7).

The desirable GCA effects for fresh storage root yield should be positive. The GCA effect of Resisto and NASPOT 1 were positive and significant $(P<0.05)$. The parents Pipi and Ogansagan had significant and negative GCA effects for fresh storage root yield (Table 7). The parent Resisto had positive and highly significant $(P<0.001)$ GCA effect for HI (Table 7). Ukerewe, Ejumula, and Pipi had significant negative GCA effects. The GCA effect was not significant for NASPOT 1, Temesgen, and Ogansagan for fresh storage root yield.

SCA effects. None of the SCA effects were significant for storage root DMC (Table 8). For $\beta$-carotene content, the families from the following crosses Ukerewe $\times$ Resisto, Resisto $\times$ Ogansagan, Ejumula $\times$ Pipi and NASPOT $1 \times$ Temesgen had positive and significant SCA effects. The crosses Ukerewe $\times$ NASPOT 1 , Ukerewe $\times$ Temesgen, Ukerewe $\times$ Ogansgen, Resisto $\times$ Ejumual, Resisto $\times$ Pipi, and Ejumula $\times$ Ogansagan had negative and highly significant SCA effects. The rest of the crosses exhibited nonsignificant SCA effects (Table 8).

The SCA effects of all the crosses were not significant for SPVD (Table 8). For fresh storage root yield, the SCA effects were not significant for most crosses except for Ukerewe $\times$ Temesgen, Resisto $\times$ Pipi, Ejumula $\times$ Ogansagan, and Pipi $\times$ Ogansagan, which had positive and significant SCA effects. Crosses with significant but negative SCA effects for storage root yield were Resisto $\times$ Ogansagan, Ejumula $\times$ Temesgen, NASPOT $1 \times$ Temesgen, and Temesgen $\times$ Ogansagan. For HI, only two crosses, Resisto $\times$ Pipi and Resisto $\times$ NASPOT 1 , had positive and significant SCA effects (Table 8). The rest of the parents had nonsignificant SCA effects.
Heterosis. Heterosis was estimated for the 24 clones selected from 420 clonal stage-I of the original $21 \mathrm{~F} 1$ families. The midparent heterosis was mostly positive for storage root DMC. Among the BPH estimates, only progenies derived from the cross Resisto $x$ Temesgen had negative estimates for storage root DMC. The highest positive midparent heterosis of $48.0 \%$ was observed for the clone, Ukerewe $\times$ NASPOT $1-1$, which was originally derived from a cross of Ukerewe $\times$ NASPOT 1 . The highest BPH of $41.3 \%$ was obtained in a clone Ukerewe $\times$ Ejumula-13, which was originally derived from the cross between Ukerewe $\times$ Ejumula (Table 9). For SPVD, a negative heterosis is desirable. A high negative midparent heterosis of $-54.2 \%$ was observed in a resistant cross of Ukerewe $\times$ Ogansagan. Other higher negative midparent heterosis of $-45.5 \%,-56.4 \%$, and $-63.6 \%$ were observed in the crosses of Resisto $x$ 
Table 6. Analysis of variance showing the significance effects of combining ability for five traits of seven sweetpotato parents and their $21 \mathrm{~F} 1 \mathrm{crosses}$ evaluated across four locations.

\begin{tabular}{|c|c|c|c|c|c|c|c|}
\hline \multirow[b]{2}{*}{ Source of variation } & \multirow[b]{2}{*}{$\mathrm{df}$} & \multirow{2}{*}{$\frac{\text { Mean square }}{\beta \text {-carotene content }(\mu \mathrm{g} / 100 \mathrm{~g})}$} & \multirow[b]{2}{*}{ df } & \multirow[b]{2}{*}{ SRDMC $(\%)$} & \multicolumn{3}{|c|}{ Mean square } \\
\hline & & & & & SPVD (1-9 score) & Fresh root yield (g/plant) & HI \\
\hline Replication $(R)$ & 1 & $4,048,715.00^{*}$ & 4 & $20.19^{\mathrm{NS}}$ & $6.38^{* * *}$ & $9,101.23^{\mathrm{NS}}$ & $0.02^{* * *}$ \\
\hline GCA & 6 & $140,772,980.37 * * *$ & 6 & $91.73 * * *$ & $2.95 * * *$ & $1,192,683.30 * * *$ & $0.34 * * *$ \\
\hline SCA & 21 & $16,973,039.16 * * *$ & 21 & $7.13^{\mathrm{Ns}}$ & $2.09 * * *$ & $96,579.60 * * *$ & $0.02 * * *$ \\
\hline $\mathrm{GCA} \times E$ & 6 & $5,207,077.88 * * *$ & 18 & $17.90^{\mathrm{Ns}}$ & $0.92 * * *$ & $458,660.10 * * *$ & $0.01 * * *$ \\
\hline $\mathrm{SCA} \times E$ & 21 & $2,574,264.94 * * *$ & 63 & $15.23^{\mathrm{NS}}$ & $0.89 * * *$ & $96,306.00 * * *$ & $0.01 * * *$ \\
\hline Pooled error & 54 & $906,010.00$ & 108 & 11.56 & 0.70 & $16,906.80$ & 0.003 \\
\hline$\% \mathrm{GCA}$ & & 70.32 & & 78.61 & 28.74 & 77.92 & 86.49 \\
\hline$\%$ SCA & & 29.68 & & 21.39 & 71.26 & 22.01 & 13.51 \\
\hline
\end{tabular}

*,**, ***Significant at $P<0.05, P<0.01$, or $P<0.001$, respectively.

$\mathrm{df}=$ degrees of freedom; $\mathrm{HI}=$ harvest index; NS = nonsignificant; SRDMC $=$ storage root dry matter content; SPVD $=$ sweetpotato virus disease.

Table 7. Estimates of the GCA effects of seven sweetpotato parents for five traits evaluated across four locations.

\begin{tabular}{llcccc}
\hline No. & Parents & SRDMC $(\%)$ & $\beta$-carotene content $(\mu \mathrm{g} / 100 \mathrm{~g})$ & SPVD $(1-9$ score $)$ & Fresh root yield $(\mathrm{g} / \mathrm{plant})$ \\
\hline 1 & Ukerewe & $1.28^{*}$ & $944.28^{* * *}$ & $-0.14^{\mathrm{Ns}}$ & $-31.65^{\mathrm{Ns}}$ \\
2 & Resisto & $-1.75^{* * *}$ & $4,098.49^{* * *}$ & $0.36^{* * *}$ & $-0.02^{*}$ \\
3 & Ejumula & $0.20^{\mathrm{Ns}}$ & $467.20^{*}$ & $-0.14^{\mathrm{Ns}}$ & $0.16^{* * *}$ \\
4 & Pipi & $1.28^{*}$ & $-1,581.35^{* * *}$ & $-0.14^{\mathrm{Ns}}$ & $-32.38^{* * *}$ \\
5 & NASPOT 1 & $-1.38^{* *}$ & $-898.27^{* * *}$ & $-0.11^{\mathrm{Ns}}$ & $-126.30^{* *}$ \\
6 & Temesgen & $0.41^{\mathrm{Ns}}$ & $-1,672.70^{* * *}$ & $89.21^{*}$ & $-0.05^{* * *}$ \\
7 & Ogansagan & $-0.05^{\mathrm{Ns}}$ & $-1,357.65^{* * *}$ & $0.25^{*}$ & $-0.02^{\mathrm{Ns}}$ \\
\hline$* * * * * *$ Signi & $-0.09^{\mathrm{Ns}}$ & $-87.93^{*}$ \\
\hline
\end{tabular}

*,**,**Significant at $P<0.05, P<0.01$, or $P<0.001$, respectively.

$\mathrm{GCA}=$ general combining ability; $\mathrm{HI}=$ harvest index; $\mathrm{NS}=$ nonsignificant; $\mathrm{SRDMC}=$ storage root dry matter content; $\mathrm{SPVD}=\mathrm{sweetpotato}$ virus disease.

Table 8. Estimates of the SCA effects involving five traits of 21 sweetpotato crosses derived from a $7 \times 7$ half diallel evaluated across four locations.

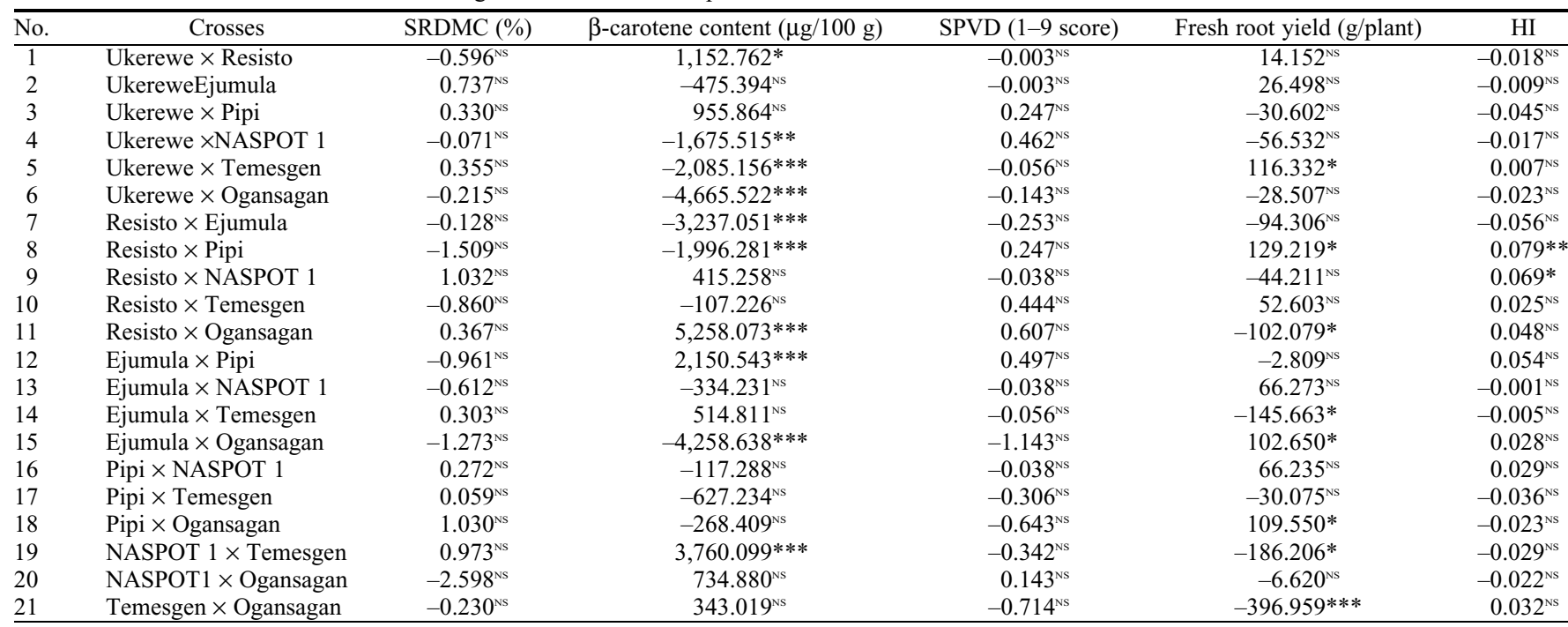

*,**, ***Significant at $P<0.05, P<0.01$, or $P<0.001$, respectively.

$\mathrm{HI}=$ harvest index; $\mathrm{NS}=$ nonsignificant; $\mathrm{RDMC}=$ storage root dry matter content; SPVD $=$ sweetpotato virus disease.

Ogansagan. High negative BPH of $-25.7 \%$ for SPVD was observed in a cross of Resisto $\times$ Ejumula and -42.9 in a cross of Resisto $x$ Ogansagan. These crosses had higher resistance to SPVD than the rest of the crosses (Table 9). Conversely, clones such as Resisto $\times$ Temesgen-10 and Resisto $\times$ Temesgen- 12 had high positive midparent heterosis of $32.7 \%$ and $33.3 \%$, respectively, and $\mathrm{BPH}$ of $20.0 \%$ and $60.0 \%$, in that order. These clones were susceptible to SPVD. Both of these clones were derived from the cross of Resisto $\times$ Temesgen.

For fresh storage root yield, high positive midparent heterosisof $83 \%$ to $170 \%$ and $45 \%$ to $62 \%$ were observed in the progenies derived from the crosses of Resisto $\times$ Pipi and Resisto $\times$ Ogansagan, respectively (Table 9). Similarly high positive BPH of $47 \%$ to $117 \%$ and $43 \%$ to $60 \%$ were observed in progenies derived from the crosses of Resisto $\times$ Pipi and Resisto $\times$ Ogansagan, respectively.

Heritability estimates. The narrow sense heritability estimates were relatively low for storage root DMC (19.0\%), SPVD (14.9\%), and fresh storage root yield $(20.4 \%)$, whereas it was relatively high for $\beta$-carotene content $(79.8 \%)$ and $\mathrm{HI}$ (48.6\%). The calculated broad sense heritability estimates were close to the narrow sense heritability. With broad sense heritability of $89.4 \%$ and $51.5 \%, \beta$-carotene content and $\mathrm{HI}$ had higher estimates than storage root DMC (20.5\%), SPVD (25.5\%), and fresh storage root yield $(22.1 \%)$.

\section{Discussion}

The presence of highly significant differences among the four test locations for all the five traits indicated that the genotypes performed differently across the test environments. The significant $\mathrm{G} \times \mathrm{E}$ interaction emphasizes the need for evaluating sweetpotato genotypes across environments. More than $75 \%$ of the crosses had a mean storage root DMC that exceeded the mean of the best parent. This shows the presence of heterosis for this trait. Similar results were reported by Chiona (2009) who estimated the presence of heterosis for storage root DMC in sweetpotato genotypes evaluated in Zambia. Crosses with high storage root DMC can be considered for continuous selection, although this depends on their $\beta$-carotene content. Resisto was the best parent that provided progenies with high $\beta$-carotene content. Most crosses had lower mean scores for SPVD across locations, which showed that all the 


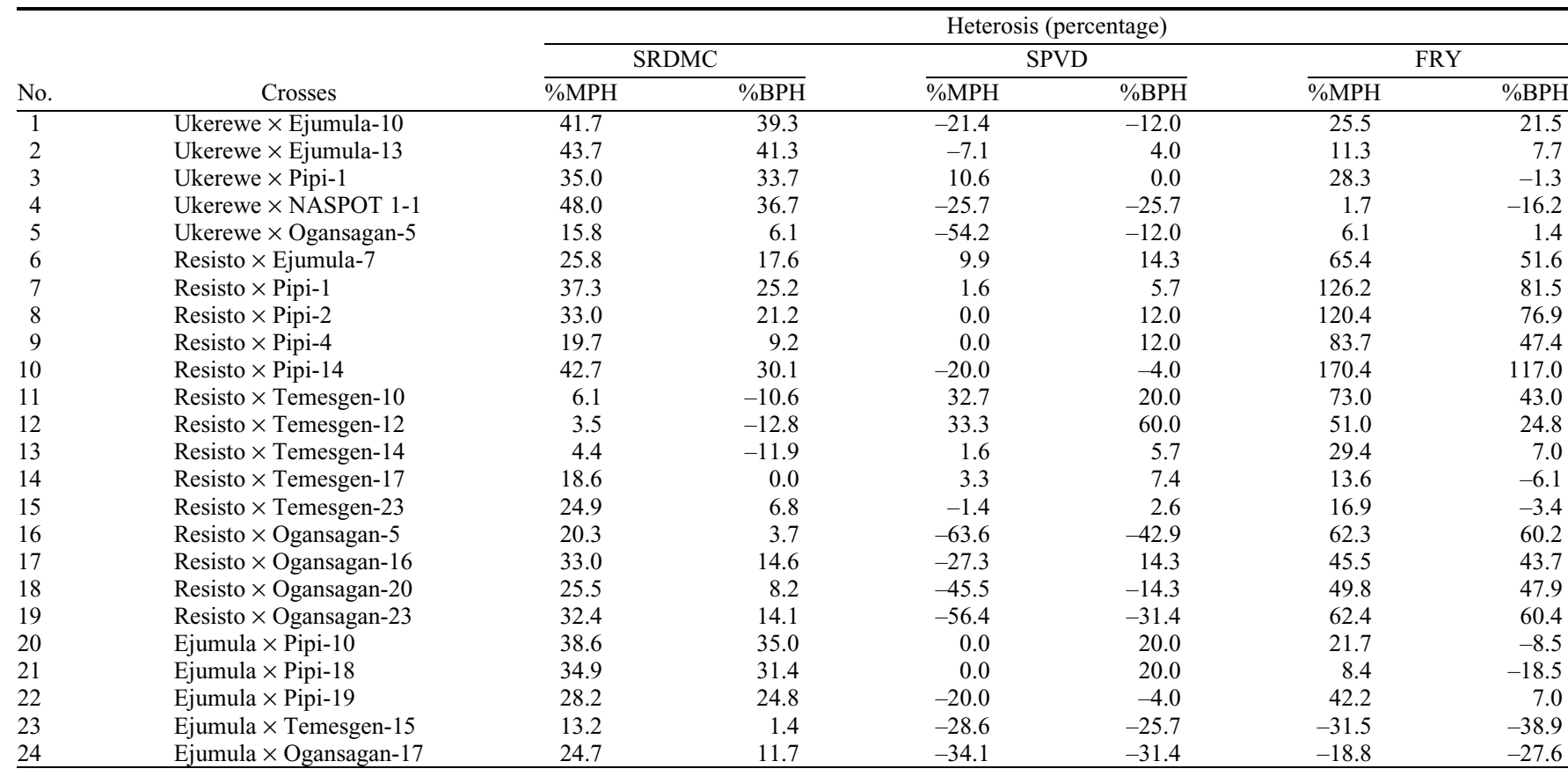

$\mathrm{BPH}=$ better-parent heterosis; FRY $=$ fresh root yield; $\mathrm{HI}=$ harvest index; $\mathrm{MPH}=$ midparent heterosis; $\mathrm{SPVD}=$ sweetpotato virus disease; $\mathrm{SRDMC}=$ storage root dry matter content.

crosses were resistant or tolerant to SPVD. However, there was a low level of SPVD infection rate during the season that the experiment was conducted suggesting the need for multiple season experiment for reliable estimation of SPVD resistance among candidate clones. Across the four test locations, some of the crosses that involved Resisto, such as Ukerewe $\times$ Resisto, Resisto $\times$ Pipi, Resisto $\times$ NASPOT 1 , and Resisto $\times$ Temesgen had higher mean fresh storage root yields that were comparable with the yield of the best parent in the cross. Crosses involving the high yielding parent, Resisto, such as Ukerewe $\times$ Resisto, Resisto $\times$ Pipi, Resisto $\times$ NASPOT 1 , and Resisto $\times$ Temesgen resulted in higher mean harvest indices that were comparable with the $\mathrm{HI}$ of Resisto.

The significance of GCA and SCA mean squares for the four traits (SPVD, fresh storage root yield, HI, and $\beta$-carotene content) indicated the importance of both additive and nonadditive gene action in controlling the expression of these traits. Similar results were reported by Chiona (2009) who found significant GCA and SCA mean squares for $\beta$-carotene, storage root DMC, HI, and fresh storage root yield in sweetpotato crosses. The GCA mean square was significant only for storage root DMC. This suggests that additive gene action is more important than nonadditive genes in controlling the expression of this trait. The GCA $\times$ environment and SCA $\times$ environment interaction effects were highly significant $(P<0.001)$ for all traits except storage root DMC. The significance of the interaction effects shows the implication of environment for selection with regard to the four traits.

All the ratios of GCA to SCA variances were close to unity for all the five traits. This implies that additive gene action was the predominant type of gene action controlling the traits. Therefore, progeny performance can be predicted based on GCA for the four traits. Mwanga et al. (2002b) reported similar results for SPVD where the ratio of GCA to SCA variances were $0.87,0.59$, and 0.51 in the screen-house, in the field, and in the recovery experiments, respectively. From their result, Mwanga et al. (2002b) suggested that GCA effects were more important than SCA effects in predicting progeny performance for SPVD resistance. Chiona (2009) reported higher ratios of GCA to SCA variances, where the ratios were $0.76,0.92,0.76$, and 0.68 for $\beta$-carotene content, RDM, HI, and fresh storage root yield, respectively.

Percent contributions of GCA and SCA were calculated from sum of squares of GCA and SCA of all the five traits and GCA contributed higher percentage in four of the traits (storage root DMC, $\beta$-carotene content, fresh storage root yield, and HI). Generally, GCA contributed 2.4-6.4 times more than SCA for the four traits. For SPVD, SCA contributed 2.5 times more than GCA, although the effects were not significant, as discussed in the later paragraphs.

The GCA effects of Ukerewe and Pipi for storage root DMC were positive and significant at $P<0.05$, suggesting the presence of additive gene action controlling the expression of this trait. All the SCA effects were not significant for this trait. This result is in agreement with the reports of other authors who indicated that GCA was more important than SCA in progeny performance for high storage root DMC (Chiona, 2009; Grüneberg et al., 2005; Sakai, 1964; Shumbusha et al., 2014b).
Both the GCA and SCA effects were important in controlling the expression of $\beta$-carotene content. Ukerewe, Resisto, and Ejumula had positive and significant GCA effects, which indicated the presence of additive gene action. Chiona (2009) reported that two high $\beta$-carotene parents exhibited positive high GCA effects, which reflected the predominance of additive gene effects in the inheritance of $\beta$-carotene. The following crosses Ukerewe $\times$ Resisto, Resisto $\times$ Ogansagan, Ejumula $\times$ Pipi, and NASPOT $1 \times$ Temesgen had positive and significant SCA effects. This shows the presence of nonadditive gene action in addition to the additive gene action. Some crosses, such as Ukerewe $x$ NASPOT 1 , Ukerewe $\times$ Temesgen, Ukerewe $\times$ Ogansagan, Resisto $\times$ Ejumula, Resisto $\times$ Pipi, and Ejumula $\times$ Temesgen had highly significant but negative SCA effects, implying undesirable combinations for improvement of this trait. It was difficult to pick one or two parents and predict the crosses that would result from these parents with good SCA effects. Parents that were included in the crosses that resulted in a significant positive SCA effect were also found in crosses that resulted in a significant negative SCA. Therefore, it would be important to make as many crosses as possible to get desirable combinations with high and positive SCA effects.

Resisto and Temesgen exhibited positive and significant GCA effects, which indicate that these parents were not good combiners for a breeding program targeting SPVD resistance. This result is supported by the reports of Sseruwu (2012) and Sibiya (2009) who reported that a positive GCA effect for disease indicates an undesirable contribution to increased susceptibility in the progeny. This is because the desirable GCA effects for SPVD 
resistance should be negative. For the rest of the parents, their GCA effects were not significant. The SCA effects of all the crosses were also not significant for this trait. This is attributed to the fact that the parents were not selected based on their resistance or susceptibility to SPVD, but they were selected based on other traits such as storage root DMC and $\beta$-carotene content.

Resisto and NASPOT 1 had positive and significant GCA effects, indicating the presence of additive gene action. The SCA effects were not significant for most of the crosses, except for the crosses Ukerewe $\times$ Temesgen, Resisto $\times$ Pipi, Ejumula $\times$ Ogansagan, and Pipi $\times$ Ogansagan, which had positive and significant SCA effects. The presence of significant and positive SCA effects suggests the contribution of nonadditive gene action for the expression of fresh storage root yield. However, it is not yet clear whether fresh storage root yield is controlled by additive or nonadditive gene action. In some studies (Chiona, 2009; Saad, 1993), it was reported that fresh storage root yield was predominantly controlled by additive gene action, whereas Vimala and Hariprakash (2011) found nonadditive gene action to controlling fresh storage root yield of sweetpotato, in agreement to the current findings.

Resisto was the only parent that had positive and highly significant $(P<0.001)$ GCA effect for HI, implying that additive gene action controls the inheritance of this trait. Only two crosses, Resisto $\times$ Pipi and Resisto $\times$ NASPOT 1 , had positive and significant SCA effects for HI, showing the existence of nonadditive gene action for the expression of this trait. Therefore, both additive and nonadditive gene actions are important for the expression of HI.

Heterosis was observed in most of the crosses for storage root DMC. All midparent heterosis estimates and most estimates of $\mathrm{BPH}$ were positive, indicating the possibility of selecting outperforming progenies than their corresponding parents. This was also reported by Chiona (2009). For SPVD, negative heterosis is desirable. Accordingly, Ukerewe $\times$ Ogansagan -5 and Resisto $\times$ Ogansagan -5 and Resisto $\times$ Ogansagan-20 and Resisto $\times$ Ogansagan-23, which resulted from the crosses of parents involving Ukerewe, Resisto, and Ogansagan, were resistant to SPVD. Sseruwu (2012) reported a negative $\% \mathrm{BPH}$ for SPVD score, which indicated a progeny that was more resistant than the best parent. Most of the F1 progenies from Temesgen, a susceptible parent, had positive mid and BPH, implying susceptibility of the cross to SPVD.

For fresh storage root yield, progenies of the cross Resisto $\times$ Pipi and Resisto $\times$ Ogansagan had higher positive mid and $\mathrm{BPH}$, indicating the possibility of selecting progenies that outperform both of their parents. These crosses had Resisto in their parentage, which had high and significant positive GCA. On the other hand, Pipi had significant negative GCA and Ogansagan did not show significant GCA effects, suggesting that heterosis does not necessarily arise from a cross involving parents with high positive GCA but also from crosses with negative GCA effects. Similar observations were reported by different authors for various traits of sweetpotato including Chiona (2009) for $\beta$-carotene content, Kivuva et al. (2015) for fresh storage root yield under drought, and Shumbusha et al. (2014b) for storage root DMC.

The narrow sense heritability $\left(h^{2}\right)$ estimates for storage root DMC, SPVD, and fresh storage root yield were low at $19.0 \%$, $14.9 \%$, and $20.4 \%$, respectively. The low $h^{2}$ for storage root DMC was unexpected as the trait is less influenced by environmental effects. The present results contrast with previous studies that reported high values of $h^{2}$ for storage root DMC (Jones, 1986; Martin, 1988). This difference may arise from the inherently high differences that exist among the genotypes within and among populations because of the high heterozygosity and hexaploidy nature of the crop. Courtney et al. (2008) reported a high broad-sense heritability of $93 \%$ for storage root DMC, among full sib families, suggesting that traditional breeding strategies such as clonal selection could improve the micronutritional value of sweetpotato. Citing different authors, Cervantes-Flores et al. (2010) also mentioned that the high narrow sense heritability and additive gene action in storage root DMC can result in rapid improvement of this trait. Bradshaw (2010) indicated that heritability of storage root DMC is estimated to be between $75 \%$ and $88 \%$, and hence selection for high DMC is very effective. In addition Cruz and Chujoy (1994) reported a narrow sense heritability of $26 \%$ to $49 \%$ for storage root DMC which is moderate to high. Two traits, namely $\mathrm{HI}$ and $\beta$-carotene content, had high narrow sense heritability estimates of $48.6 \%$ and $79.8 \%$, respectively. The high $h^{2}$ obtained in this study for $\beta$-carotene content deviates from the results reported by Chiona (2009) who reported low $h^{2}$. However, the current result is in agreement with the reports of Jones (1986) and Martin (1988) who reported that flesh color, skin color, percent dry weight, percent crude starch, resistance to root-knot nematode, and vine length had high heritabilities.

Fresh storage root yield and SPVD had lower $h^{2}$, which was expected because these traits are highly influenced by environmental effects. Vimala and Hariprakash (2011) reported that fresh storage root yield had low heritability, indicating the presence of nonadditive gene action. The estimates of broad sense heritability were also close to the narrow sense heritability. The $\beta$-carotene content and $\mathrm{HI}$, which had higher narrow sense heritability of $79.8 \%$ and $48.6 \%$, respectively, also had higher estimates of broad sense heritability of $89.4 \%$ and $51.5 \%$, respectively. SPVD, fresh storage root yield, and storage root DMC had lower estimates of broad-sense heritability of $25.5 \%, 22.1 \%$ and $20.5 \%$, respectively. When broad sense heritability estimates are close to narrow sense heritability then nonadditive gene action is lower than the additive gene action. In general, heritability estimates represent an efficient means of determining the response to selection (Jones, 1986).

\section{Conclusions}

From the results of this study it is concluded that additive gene action is more important for the improvement of storage root DMC, whereas both additive and nonadditive gene actions were important in controlling the expression of the $\beta$-carotene content. For all the traits studied, additive gene action was the predominant type of gene action controlling the traits, and therefore, progeny performance can be predicted based on GCA. Based on GCA effects, Pipi and Temesgen were better parents for storage root DMC, whereas Ukerewe and Resistowere better parents for the $\beta$-carotene content. For fresh storage root yield, Resisto and NASPOT 1 were better parents. However, Temesgen was not a good combiner for resistance breeding to control SPVD. Resisto was the best parent for improved HI.

Based on SCA effects, Ukerewe $\times$ Resisto, Resisto $\times$ Ogansagan, and Ejumula $\times$ Pipi were promising families for improvement of the $\beta$-carotene content. For fresh storage root yield, Ukerewe $\times$ Temesgen, Resisto $\times$ Pipi, Ejumula $\times$ Ogansagan, and Pipi $\times$ Ogansagan were superior families. Crosses derived from Resisto, such as Ukerewe $\times$ Resisto, Resisto $\times$ Pipi, Resisto $\times$ NASPOT 1 , and Resisto $\times$ Temesgen were promising families to improve HI.

Positive heterosis was observed in some of the crosses and because clonal reproduction is used in sweetpotato, the heterozygous F1 progenies can be screened, selected, evaluated and released as a variety. Therefore, sweetpotato breeding can take advantage of both GCA effect, where poly-crosses can be applied to improve the traits of interest, and SCA effect, where progeny selection showing heterosis for the traits of interest would be possible. The HI and $\beta$-carotene content had high heritability, whereas storage root DMC, SPVD, and fresh storage root yield had relatively low heritability.

Crosses with the high $\beta$-carotene content were Ukerewe $\times$ Resisto, Resisto $\times$ Ogansagan, Ejumula $\times$ Pipi, and NASPOT $1 \times$ Temesgen. These crosses had high storage root DMC that exceeded the mean of the best parent. These families also had medium to high mean fresh storage root yield. Therefore, it is worth undertaking continuous progeny selection among these families to develop OFSP varieties with high storage root DMC for further evaluation and release.

\section{Literature Cited}

AARC. 2015. Sweet potato production and field management in Ethiopia. Production manual. Awassa Agricultural Research Center, Hawassa, Ethiopia.

Andrade, M., I. Barker, D. Cole, S. Fuentes, W. Gruneberg, R. Kapinga, J. Kroschel, R. Labarta, B. Lemaga, C. Loechl, J. Low, O. 
Ortiz, A. Oswald, and G. Thiele. 2009. Unleashing the potential of sweetpotato in sub-saharan Africa: Current challenges and way forward. International Potato Center (CIP), Lima, Peru.

Baker, R.J. 1978. Issues in diallel analysis. Crop Sci. 18:533-536.

Bradshaw, J.E. 2010. Root and tuber crops. Hand book of plant breeding. Springer, New York, NY.

Burri, B.J. 2011. Evaluating sweetpotato as an intervention food to prevent vitamin A deficiency. Compr. Rev. Food Sci. Food Saf. 10:118-130.

Cervantes-Flores, J., B. Sosinski, K. Pecota, R.O.M. Mwanga, G. Catignani, V. Truong, R. Watkins, M. Ulmer, and G. Yencho. 2010. Identification of quantitative trait loci for dry matter, starch and $\beta$-carotene content in sweetpotato. Mol. Breed. 5:1-16.

Chiona, M. 2009. Towards enhancement of $\beta$-carotene content of high dry mass sweetpotato genotypes in Zambia. University of KwaZulu-Natal, Pietermaritzburg, South Africa, $\mathrm{PhD}$ Diss.

Courtney, M., M. Mcharo, D. La Bonte, and W. Gruneberg. 2008. Heritability estimates for micronutrient composition of sweetpotato storage roots. Hort. Sci. 43:1382-1384.

Cruz, T.L.G. and E. Chujoy. 1994. Heritability estimates of some root characters in sweet potatoes. Philipp. J. Crop Sci. 19:27-32.

CSA. 2015. Ethiopia agricultural sample survey 2014/2015: Report on land utilization (private peasant holdings, Meher season). Central Statistical Agency (CSA), Federal Democratic Republic of Ethiopia, Addis Ababa, Ethiopia.

Falconer, D.S. and T.F.C. Mackay. 1996. Introduction to quantitative genetics. Longman, London, UK.

Gardner, C.O. 1967. Simplified methods for estimating constants and computing sums of squares for a diallel cross analysis. Fitotec. Latinoam. 4:1-12.

Gardner, C.O. and S.A. Eberhart. 1966. Analysis and interpretation of the variety cross diallel and related populations. Biometrics 22:439452.

Gichuki, S., M. Berenyi, D. Zhang, M. Hermann, J. Schmidt, J. Glössl, and K. Burg. 2003. Genetic diversity in sweetpotato [Ipomoea batatas (L.) Lam.] in relationship to geographic sources as assessed with RAPD markers. Genet. Resources Crop Evol. 50:429-437.

Griffing, B. 1956a. A generalized treatment of the use of diallel crosses in quantitative inheritance. Heredity 10:31-50.

Griffing, B. 1956b. Concept of general and specific combining ability in relation to diallel crossing system. Austral. J. Biol. Sci. 9:463-493.

Grüneberg, W.J., R. Eyzaguirre, J. Espinoza, R.O.M. Mwanga, M. Andrade, H. Dapaah, S. Tumwegamire, S. Agili, F.P. Ndingo-Chipungu, S. Attaluri, R. Kapinga, T. Nguyen, X. Kaiyung, K. Tjintokohadi, T. Carey, and J. Low. 2010. Procedures for the evaluation and analysis of sweetpotato trials. International Potato Center, Lima, Peru.

Grüneberg, W.J., D. Ma, R.O.M. Mwanga, and E.E. Carey, et al.2015. Advances in sweetpotato breeding from 1993 to 2012. In: J. Low, M. Nyongesa, S. Quinn, and M. Parker (eds.). Potato and sweetpotato in Africa: Transforming the value chains for food and nutrition security. CAB International, Wallingford, UK.

Grüneberg, W.J., K. Manrique, D. Zhang, and M. Hermann. 2005. Genotype $\times$ environment interactions for a diverse set of sweetpotato genotypes evaluated across varying ecological conditions in Peru. Crop Sci. 45:2160-2171.
Gurmu, F., S. Hussein, and M. Laing. 2015a. Diagnostic assessment of sweetpotato production in Ethiopia: Constraints, post-harvest handling and farmers' preferences. Res. Crops 16(1):104-115.

Gurmu, F., S. Hussein, and M. Laing. 2015b. The potential of orange-fleshed sweetpotato to prevent vitamin A deficiencyin Africa. Intl. J. Vitam. Nutr. Res. 84(1-2):65-78.

Hahn, S.K. 1979. Effects of virus (SPVD) on growth and yield of sweetpotato. Expt. Agr. $15: 253-256$

Hallauer, A.R., M.J. Carena, and J.B.M. Filho. 2010. Quantitative genetics in maize breeding. Springer, New York, NY.

HarvestPlus. 2014. Getting nutritious foods to people. The 2nd Global Conference on Biofortification, 31 Mar.-2 Apr. 2014, Kigali, Rwanda.

HarvestPlus. 2017. Driving impact: HarvestPlus annual report 2016. Washington, DC.

Hayman, B.I. 1954. The analysis of variance of diallel tables. Biometrics 10:235-244.

Hayman, B.I. 1958. The theory and analysis of diallel crosses. Genetics 43:63-85.

Jinks, J.L. and B.I. Hayman. 1953. The analysis of diallel crosses. Maize Genet. Coop. News Lett. 27:48-54.

Jones, A. 1986. Sweetpotato heritability estimates and their use in breeding. Hort. Sci. 21:14-17.

Jones, A., P.D. Dokcs, J.M. Schalk, M.G. Hamilton, M.A. Mullen, R.A. Baumgardner, D.R. Paterson, and T.A. Boswell. 1983. 'Resisto' sweet potato. HortScience 18:251-252.

Kapinga, R.S., S. Tumwegamire, J. Ndunguru, M.I. Andrade, S. Agili, R.O.M. Mwanga, S. Laurie, and H. Dapaah. 2010. Catalogue of orangefleshed sweetpotato varieties for SSA. International Potato Center (CIP), Lima, Peru.

Karyeija, R.F., R.W. Gibson, and J.P.T. Valkonen. 1998. Resistance to sweet potato virus disease (SPVD) in wild East African Ipomoea. Ann. Appl. Biol. 133(1):39-44.

Kempthorne, O. 1956. The theory of the diallel cross. Genetics 41:451-459.

Kempthorne, O. 1957. An introduction to genetic statistics. Wiley, New York, NY.

Kivuva, B.M., M.G. Stephen, Y. Craig, and J. Sybia. 2015. Combining ability and heterosis for yield and drought tolerance traits under managed drought stress in sweetpotato. Euphytica 201(3):423-440.

Lebot, V. 2010. Sweetpotato. In: J.E. Bradshaw (ed.). Root and tuber crops. Springer, New York, NY.

Low, J., T. Walker, and R. Hijmans. 2001. The potential impact of orange-fleshed sweetpotatoes on vitamin A intake in sub-saharan Africa. In: A regional workshop on food-based approaches to human nutritional deficiencies. The VITAA Project, Vitamin A and Orange-fleshed Sweetpotatoes in Sub-Saharan Africa, 9-11 May, 2001, Nairobi. International Potato Center (CIP), Nairobi, Kenya.

Low, J.W., R.O.M. Mwanga, M. Andrade, E. Carey, and A. Ball. 2017. Tackling vitamin A deficiency with biofortified sweetpotato in SSA. Glob. Food Secur. 14:23-30.

Martin, F.W. 1988. Genetic and physiological basis for breeding and improving the sweet potato. In: L. Degras (ed.). Proc. 8th Symp. Intl. Soc. Trop. Root Crops, INRA, Paris, Guadeloupe, French West Indies.

Mwanga, R.O.M., A. Kriegner, J.C. CervantesFlores, D.P. Zhang, J.W. Moyer, and G.C. Yencho. 2002a. Resistance to sweetpotato chlorotic stunt virus and sweetpotato feathery mottle virus is mediated by two separate re- cessive genes in sweetpotato. J. Amer. Soc. Hort. Sci. 127:798-806.

Mwanga, R.O.M., B. Odongo, C. Niringiye, A. Alajo, P.E. Abidin, R. Kapinga, S. Tumwegamire, B. Lemaga, J. Nsumba, and E.E. Carey. 2007. Release of two orange-fleshed sweetpotato varieties, 'SPK004' ('Kakamega') and 'Ejumula' in Uganda. HortScience 42:1728-1730.

Mwanga, R.O.M., B. Odongo, G. Turyamureeba, A. Alajo, G.C. Yencho, R.W. Gibson, N.J.M. Smit, and E.E. Carry. 2003. Release of six sweetpotato varietyies ('NASPOT 1 to NASPOT 6') in Uganda. HortScience 38:475-476.

Mwanga, R.O.M., G.C. Yencho, and J.W. Moyer. 2002b. Diallel analysis of sweetpotatoes for resistance to sweetpotato virus disease. Euphytica 128:237-248.

Ndunguru, J., R. Kapinga, P. Sseruwagi, B. Sayi, R. Mwanga, S. Tumwegamire, and C. Rugutu. 2009. Assessing the sweetpotato virus disease and its associated vectors in northwestern Tanzania and central Uganda. Afr. J. Agr. Res. 4(4:334-343.

Payne, R.W., D.A. Murray, S.A. Harding, D.B. Baird, and D.M. Soutar. 2011. GenStat for windows (14th edition) introduction. VSN International, Hemel Hempstead, UK.

Rodriguez-Amaya, D.B. 2001. A guide to carotenoid analysis in foods. ILSI Human Nutrition Institute, United States of America, Washington, DC.

Saad, M.S.B. 1993. Variability, divergence, heterosis, combining ability, and yield component studies in sweetpotato [Ipomoea batatas (L.) Lam.] from Sabah and Sarawak, Malaysia. Universiti Pertanian, Malaysia, PhD Diss.

Sakai, K. 1964. Studies on the enlargement of varieties and the improvement of selection methods in sweetpotato breeding. Bull. Kyushu Agr. Expt. Sta. 9:247-397.

SAS Institute Inc. 2003. Version 9.1. SAS Institute Inc., Cary, NC.

Shumbusha, D., J. Ndirigwe, L. Kankundiye, A. Musabyemungu, D. Gahakwa, P.S. Ndayemeye, and R.O.M.M. D., G. Tusiime, R. Edema, P. Gibson, E. Adipala, and R.O.M. Mwanga. 2014b. Inheritance of root dry matter content in sweetpotaton. Afr. Crop Sci. J. 22(1):69-78.

Sibiya, J. 2009. Breeding investigation for resistance to Phaeosphaeria leaf spot and other important foliar diseases and a study of yield stability in African maize germplasm. University of KwaZulu-Natal, Pietermaritzburg, South Africa, PhD Diss.

Sseruwu, G. 2012. Breeding of sweetpotato [Ipomoea batatas (L.) Lam.] for storage root yield and resistance to Alternaria leaf petiole and stem blight (Alternaria spp.) in Uganda. University of KwaZulu-Natal, Pietermaritzburg, South Africa, PhD Diss.

Tadesse, T. 2006. Evaluation of root yield and carotene content of orange-fleshed sweetpotato clones across locations in southern region of Ethiopia. Hawassa University, Hawassa, Ethiopia, MSc Diss.

Teye, E. and E.E. Abano. 2012. Physical properties of two varieties of sweet potato grown in coastal savannah zone of Ghana. Intl. J. Sci. Nat. 3(1): 105-109.

Tofu, A., T. Anshebo, E. Tsegaye, and T. Tadesse. 2007. Summary of progress on orange-fleshed sweetpotato research and development in Ethiopia. In: Proc. 13th Intl. Soc. Trop. Root Crops (ISTRC) Symp., 9-15 Nov. 2007, Arusha. ISTRC, Arusha, Tanzania.

van Jaarsveld, P.J., M. Faber, S.A. Tanumihardjo, P. Nestel, C.J. Lombard, and A.J.S. Benadé. 2005. Beta carotene-rich orange-fleshed sweet 
potato improves the vitamin A status of primary school children assessed with the modified-relative-dose-response test. Amer. J. Clin. Nutr. 81:1080-1087.

Vimala, B. and B. Hariprakash. 2011. Variability of morphological characters and dry matter content in the hybrid progenies of sweetpotato [Ipomoea batatas (L.) Lam.]. Gene Conserve 10:65-86.
Wang, Z., J. Li, Z. Luo, L. Huang, X. Chen, B. Fang, Y. Li, J. Chen, and X. Zhang. 2011. Characterization and development of EST-derived SSR markers in cultivated sweetpotato (Ipomoea batatas). BMC Plant Biol. 11:131-139.

WHO. 2009. Global prevalence of vitamin A deficiency in population at risk from 1995-2005. WHO global database on vitamin A defficiency. World Health Organization, Geneva, Switzerland.
Zhang, D., J. Cervantes, Z. Huam'an, E. Carey, and M. Ghislain. 2000. Assessing genetic diversity of sweetpotato [Ipomoea batatas (L.) Lam.] varieties from tropical America using AFLP. Genet. Resources Crop Evol. 47:659-665.

Zhang, Y., M.S. Kang, and K.R. Lamkey. 2005. DIALLEL-SAS05: A comprehensive program for Griffing's and Gardner-Eberhart analyses. Agron. J. 97:1097-1106. 